\title{
Nodulation, Growth, and Yield of Soybean (Glycine max L. Merrill) as Affected by Bio-, Organic, and Inorganic NPSB Fertilizers, and Lime in Assosa Zone, Western Ethiopia
}

\author{
Abiyot Abeje $\mathbb{D}^{1},{ }^{1}$ Getachew Alemayehu, ${ }^{1}$ and Tesfaye Feyisa ${ }^{2}$ \\ ${ }^{1}$ Bahir Dar University, College of Agriculture and Environmental Sciences, Bahir Dar, Ethiopia \\ ${ }^{2}$ Amhara Agricultural Research Institute (ARARI), Bahir Dar, Ethiopia \\ Correspondence should be addressed to Abiyot Abeje; abiyotabeje@gmail.com
}

Received 20 April 2021; Revised 25 July 2021; Accepted 14 September 2021; Published 27 September 2021

Academic Editor: Mehdi Rahimi

Copyright (c) 2021 Abiyot Abeje et al. This is an open access article distributed under the Creative Commons Attribution License, which permits unrestricted use, distribution, and reproduction in any medium, provided the original work is properly cited.

\begin{abstract}
The productivity of soybean in Assosa Zone particularly in Assosa and Bambassi districts is very low due to poor soil fertility management practices that resulted in severe soil acidity and low $\mathrm{N}$-fixing inoculants in the soil. Hence, this experiment was conducted during the main cropping season of 2019 and 2020 in Assosa and Bambassi districts to evaluate the effect of biofertilizers, organic fertilizers, inorganic NPSB fertilizers, and lime on nodulation, growth, and yield of soybean (Glycine $\max$ L. Merrill). Factorial combinations of two biofertilizer inoculants (without biofertilizer (B1) and SB12 plus MAR1495 biofertilizers at their recommended rates of $500 \mathrm{~g} \cdot \mathrm{ha}^{-1}$ (B2); two organic fertilizers: without fresh cattle manure (M1) and fresh cattle manure at $10 \mathrm{t} \cdot \mathrm{ha}^{-1}$ (M2); two lime rates: without lime (L1) and lime at $5 \mathrm{t} \cdot \mathrm{ha}^{-1}$ (L2); two inorganic NPSB fertilizers: NPSB at 9.5-23-3.5-0.05 (F1) and NPSB at 19-46-7-0.1 (F2) at their recommended rates for soybean) were laid out in a randomized complete block design with three replications. Effective nodules, leaf area index, and grain yield were collected and analyzed using SAS 9.1.3 software. Results of the experiment showed that effective nodules, leaf area index, grain yield, bulk density, $\mathrm{pH}$, total nitrogen, available phosphorus, organic carbon, and cation exchange capacity were highly $(P<0.01)$ affected by the interaction of bio-, organic, and inorganic fertilizers and lime at both locations and years. Across all treatments, the grain yield of soybean was increased in the second year, while it was lowest in the first year at both locations. Finally, the interaction of SB12 + MAR1495, $10 \mathrm{t} \cdot \mathrm{ha}^{-1}$ fresh cattle manure, without lime, and NPSB at 19-46-7-0.1 increased the grain yield of soybean in both Assosa and Bambassi districts and should be adopted appropriately to enhance the productivity of soybean in the areas and similar agroecologies, while the interaction effect of SB12 + MAR 1495,10 tha $^{-1}$ FCM, $5 \mathrm{t} \cdot \mathrm{ha}^{-1}$ lime, and NPSB at 19-46-7-0.1 improved soil physicochemical properties in both the districts and similar agroecologies.
\end{abstract}

\section{Introduction}

Soybean (Glycine max L. Merrill) is an economically important leguminous crop containing substantial amounts of all the essential amino acids, oil, minerals, and vitamins, and it is regarded as a nutrient storage [1]. It is also the most important legume worldwide, which can be used for a variety of purposes including human food, animal feed, soy milk, oil, and its role in soil amelioration [2]. Soybean has an average protein content of $40 \%$ and is more protein-rich than any of the common vegetable or animal food sources [3]. Soybean seeds also contain about $20 \%$ oil on a dry matter basis, and this is $85 \%$ unsaturated and cholesterol-free [4]. It is highly industrialized in developed countries, providing more than a quarter of the world's food [5]. Globally, 349.31 million metric tons of soybean was produced in 2016 with an average productivity of $3.21 \mathrm{t} \cdot \mathrm{ha}^{-1}$. From 349.31 million metric tons, USA accounted for $34 \%$ (the leading producer) followed by Brazil accounting for $30 \%$ and Argentina accounting for $18 \%[6]$. 
In Ethiopia, soybean contributes nearly 10 percent to the country's total oilseed production and accounts for only 4 percent of area planted to oilseeds. Due to the increasing demand for soybean as a cash crop, the production has reached to $86,467.869$ tons with an average productivity of $2.271 \mathrm{t} \cdot \mathrm{ha}^{-1}$. Despite the increasing demand for soybean as a cash crop in the country, the average productivity of soybean in Ethiopia is still below the world average productivity of $3.21 \mathrm{t} \cdot \mathrm{ha}^{-1}$ and its potential productivity that could go up to $4 \mathrm{t} \cdot \mathrm{ha}^{-1}$, which may be related to soil constraints and management of the crop [7].

In addition, the total production of soybean is still below the expected level and does not meet the country's oil demand and other soybean products. Due to this fact, still Ethiopia imported 522,000 metric tons of cooking oil, valued at nearly $\$ 530$ million in the year 2017 . Of this imported oil, more than 87 percent by volume was palm oil; and Ethiopia imports 15 million kilograms of soybean products and spends 11 million USD for importing various soybean products every year [7].

Soybean production is increasing in Western Ethiopia, driven by its high value for food, oil, feed, and its ability to improve soil fertility [8]. Despite the increasing demand for soybean in Western Ethiopia, the average productivity of soybean $\left(2.138 \mathrm{t} \cdot \mathrm{ha}^{-1}\right)$ in Western Ethiopia particularly in Assosa and Bambassi districts is very low compared with the national picture [7]. The major factors that limit the productivity of soybean in Western Ethiopia particularly in Assosa and Bambassi districts are soil acidity, low $\mathrm{N}$-fixing Bradyrhizobium japonicum strains, and poor soil management practices [9].

According to Zelleke et al. [10], the productivity of soybean has never reached its full potential of production due to inappropriate nutrient management in Assosa and Bambassi districts, Assosa Zone, Western Ethiopia. According to Assosa Agricultural Research Center [9], most of the soils in Assosa and Bambassi districts are acidic with $\mathrm{pH}$ of 5.2-6.0. Zelleke et al. [10] also reported that native population of Bradyrhizobium japonicum strains was very low in the soils of Assosa and Bambassi districts. Assosa Agricultural Research Center [9] also reported that there were poor soil management practices in Assosa and Bambassi districts and as a result nutrient deficiencies have been observed. According to Dibabe [11], most agricultural soils of Western Ethiopia are deficient in nitrogen, phosphorus, sulfur, and boron nutrients. According to Khaliq and Abbasi [12], degradation of soil due to repeated application of inorganic fertilizers to the farm land has been observed in Western Ethiopia.

In Assosa and Bambassi districts where this experiment was conducted, there were not many concurrent studies conducted to evaluate the combined effects of biofertilizers, organic fertilizers, inorganic fertilizers, and lime on soybean production. These problems make farmers not to meet soybean nutrient demand over large area. These problems are therefore can be ameliorated by the combined application of biofertilizers, organic fertilizers, inorganic fertilizers, and lime in Assosa and Bambassi districts, Assosa Zone, Western Ethiopia.
Jones [13] reported that the combined application of manure, lime, and inorganic fertilizers on inoculated soybean produced the highest nodule number, effective nodules, nodule fresh weight, nodule dry weight, and nodule volume per plant. Bambara and Ndakidemi [14] also reported that the combined application of biofertilizers, organic fertilizers, lime, and inorganic fertilizers increased all the nodulation parameters of soybean. Similarly, Shirpurkar et al. [15] reported that the integrated application of biofertilizers, fresh cattle manure at $10 \mathrm{t} \cdot \mathrm{ha}^{-1}$, and inorganic fertilizers at their recommended doses increased the values of leaf area index, total dry matter, pod length, number of pods per plant, seeds per pod, and hundred seed weight and ultimately increased the grain yield and harvest index of soybean. Nekesa et al. [16] also reported the positive response of soybean grain yield to lime application either alone or combined with P fertilizer. Rathke et al. [17] reported that the grain and biomass yield of soybean increased significantly due to increased sulfur levels from 0 to $40 \mathrm{~kg} \cdot \mathrm{S} \cdot \mathrm{ha}^{-1}$. Ross et al. [18] observed higher grain yield production in soybeans and concluded that this higher productivity was related to leaf nutrient replenishment through boron fertilization, resulting in sustained maintenance of the photosynthetic rate. In addition, Singh [19] observed that B fertilization resulted in significantly higher dry matter accumulation resulting in maximum grain yield. Shirpurkar et al. [15] also reported that the integrated application of biofertilizers, fresh cattle manure at $10 \mathrm{t} \cdot \mathrm{ha}^{-1}$, and inorganic fertilizers at their recommended doses increased the grain yield of soybean. Thus, to avail smallholder farmers to choose best fit option, the current experiment was conducted with the objectives to investigate the combined effects of biofertilizer, organic fertilizer, inorganic fertilizer, and lime on the nodulation, growth, and yield of soybean in Assosa and Bambassi districts, Assosa Zone, Western Ethiopia.

\section{Materials and Methods}

2.1. Descriptions of the Experimental Sites. The experiment was carried out for two years (2019-2020) during the main rainy season in Assosa and Bambassi districts, Assosa Zone, Western Ethiopia. Geographically, Assosa is located at $10^{\circ} 02^{\prime} 05^{\prime \prime} \mathrm{N}$ latitude and $34^{\circ} 34^{\prime} 09^{\prime \prime}$ E longitude at an elevation of 1570 meter above sea level, while Bambassi is located at $9^{\circ} 23^{\prime} 22^{\prime \prime} \mathrm{N}$ latitude and $34^{\circ} 00^{\prime} 12^{\prime \prime} \mathrm{W}$ longitude at an elevation of 1470 meter above sea level. Both experimental sites are characterized by hot humid agroecology having a monomodal rainfall distribution pattern, which starts at the end of April and extends to mid-November, with the maximum rainfall received in June to October. In 2019 and 2020 cropping seasons, the mean annual rainfall at Assosa was $1221.7 \mathrm{~mm}$ and $1235.4 \mathrm{~mm}$, respectively (Figure 1), while it was $1209.1 \mathrm{~mm}$ and $1226.2 \mathrm{~mm}$ at Bambassi, respectively (Figure 2).

In addition, the minimum and maximum temperatures of Assosa in the 2019 cropping season were $16.5^{\circ} \mathrm{C}$ and $27.5^{\circ} \mathrm{C}$ and in 2020 were $16.7^{\circ} \mathrm{C}$ and $27.9^{\circ} \mathrm{C}$, respectively (Figure 1); whereas the minimum and maximum 


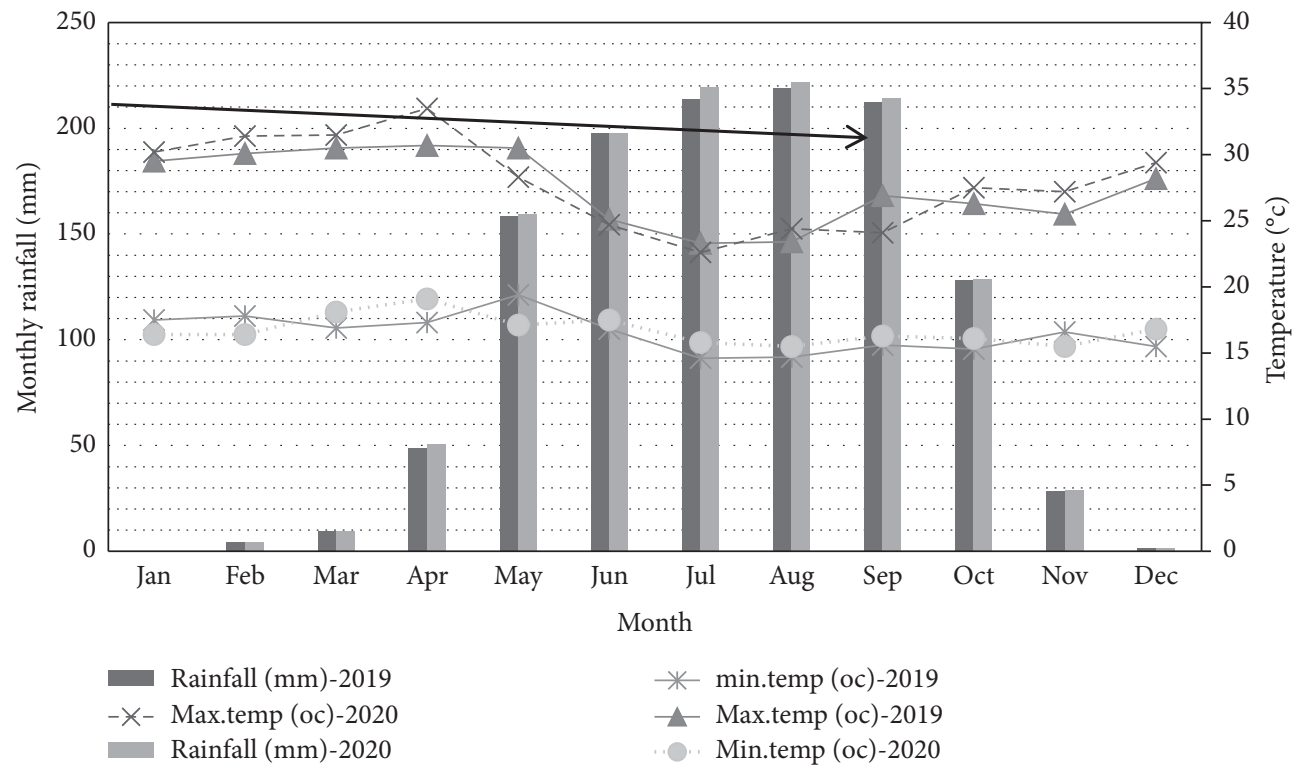

Figure 1: Average monthly rainfall and temperature distribution during 2019 and 2020 experimental years in Assosa.

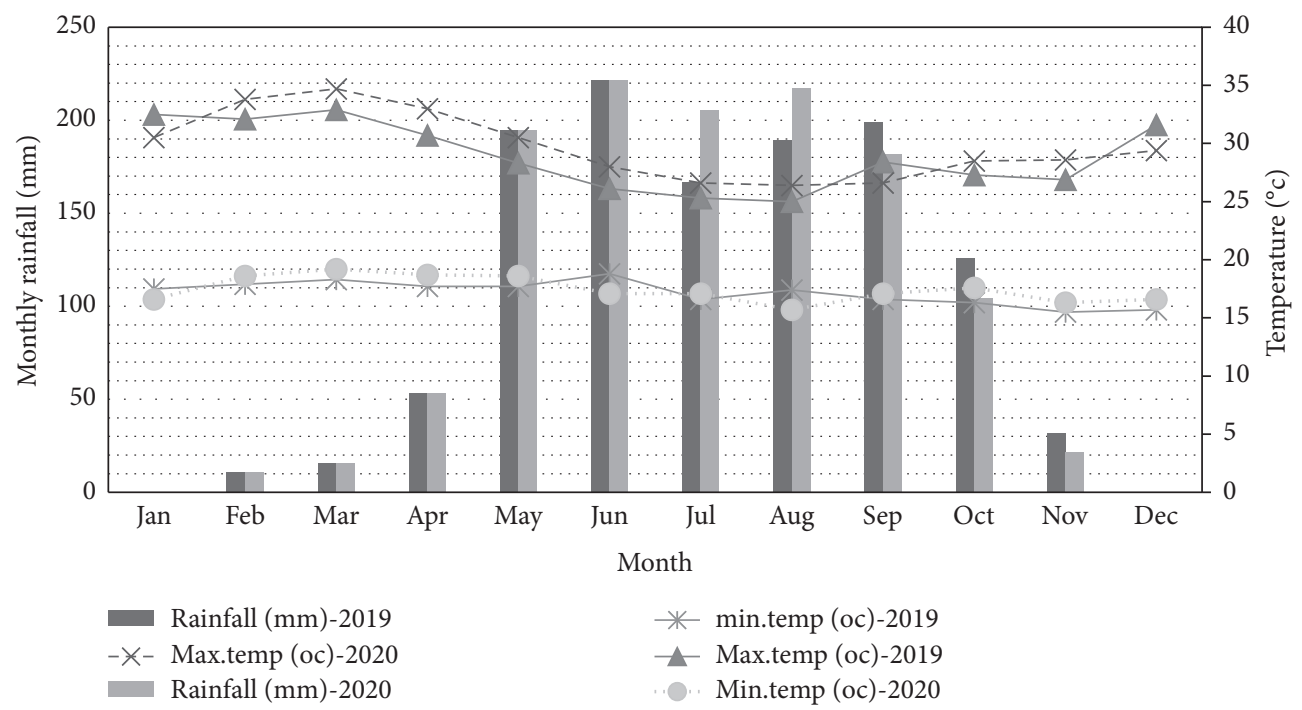

FIGURE 2: Average monthly rainfall and temperature distribution during 2019 and 2020 experimental years in Bambassi.

temperatures of Bambassi in 2019 were $17.2^{\circ} \mathrm{C}$ and $28.9^{\circ} \mathrm{C}$ and in 2020 were $17.4^{\circ} \mathrm{C}$ and $29.7^{\circ} \mathrm{C}$, respectively (Figure 2).

Based on initial soil analysis results, the texture of soil was clay with more than $50 \%$ clay content at both locations (Table 1). The bulk densities of the experimental sites were $1.16,1.23$, and $1.19 \mathrm{~g} \cdot \mathrm{cm}^{-3}$ for Assosa, Bambassi, and combined over locations, respectively, which are in the suitable ranges for agricultural practices. The $\mathrm{pH}$ values of soil were 5.32, 5.50, and 5.41 for Assosa, Bambassi, and combined over locations, respectively, and were all strongly acidic in nature at both locations (Table 1). In soils having a $\mathrm{pH}$ of the aforementioned range, phosphorus fixation is a serious problem and also useful microorganisms including nitrogen-fixing rhizobia could not survive for they need a soil $\mathrm{pH}$ above 5.5. At Assosa, total nitrogen (0.20\%), available $\mathrm{P}$ (6.80 ppm), organic carbon $(2.80 \%)$, and effective cation exchange capacity $\left(22.05 \mathrm{cmol}(+) \mathrm{kg}^{-1}\right)$ were medium, low, high, and moderate, respectively, for effective crop growth. Likewise, at Bambassi, total nitrogen (0.49\%), available P (5.49 PPM), organic carbon (3.30\%), and cation exchange capacity $\left(25.61 \mathrm{cmol}(+) \mathrm{kg}^{-1}\right)$ were high, low, very high, and very high, respectively, for effective crop growth.

The mean results over combined locations showed that total nitrogen $(0.34 \%)$, available $\mathrm{P}(6.14 \mathrm{ppm})$, organic carbon $(3.05 \%)$, and cation exchange capacity $(23.83 \mathrm{cmol}$ (+) $\mathrm{kg}^{-1}$ ) of soil were high, low, high, and moderate, respectively, for effective crop growth. This implies that the experimental soil apparently contains low to very high levels of soil quality parameters initially to support plant growth (Table 1). This is in agreement with standardizations of Hazelton and Murphy [20] who categorized a soil with $\mathrm{pH}$ (5.41) as strongly acidic. $3.05 \%$ organic carbon and $0.34 \%$ 
TABLE 1: Initial soil physicochemical properties of the experimental sites.

\begin{tabular}{|c|c|c|c|c|c|c|}
\hline Soil properties & Assosa & Rating & Bambassi & Rating & COS & Rating \\
\hline \multicolumn{7}{|l|}{ Physical properties } \\
\hline Bulk density $\left(\mathrm{g} \mathrm{cm}^{-3}\right)$ & 1.16 & Low* & 1.23 & Low* & 1.19 & Low* \\
\hline \multicolumn{7}{|l|}{ Particle size distribution } \\
\hline Sand (\%) & 24.00 & & 21.33 & & 22.66 & \\
\hline Clay (\%) & 53.00 & & 52.34 & & 52.67 & \\
\hline Silt (\%) & 23.00 & & 26.33 & & 24.66 & \\
\hline Textural class & Clay & & Clay & & Clay & \\
\hline \multicolumn{7}{|l|}{ Chemical properties } \\
\hline $\mathrm{pH}\left(\mathrm{H}_{2} \mathrm{O}\right)$ & 5.32 & Strongly acidic* & 5.50 & Strongly acidic* & 5.41 & Strongly acidic* \\
\hline Total nitrogen (\%) & 0.20 & Medium* & 0.49 & High* $^{*}$ & 0.34 & High* \\
\hline Available P (ppm) & 6.80 & Low* & 5.49 & Low ${ }^{*}$ & 6.14 & Low $^{*}$ \\
\hline Organic carbon $(\%)$ & 2.80 & High* & 3.30 & Very high* & 3.05 & High* $^{*}$ \\
\hline $\mathrm{CEC}\left(\mathrm{meq} 100 \mathrm{~g} \mathrm{soil}^{-1}\right)$ & 22.05 & Moderate* & 25.61 & Very high* & 23.83 & Moderate* \\
\hline
\end{tabular}

${ }^{*}$ According to [20]. $\mathrm{CEC}=$ cation exchange capacity; $\mathrm{P}=$ phosphorus; $\mathrm{ppm}=$ part per million; $\mathrm{pH}=$ power of hydrogen; $\mathrm{COS}=$ combined over sites.

nitrogen were considered as high in standards. Similarly, $6.14 \mathrm{ppm}$ phosphorus was categorized as low, and the cation exchange capacity $\left(23.83 \mathrm{cmol}(+) \mathrm{kg}^{-1}\right.$ of soil $)$ was moderate with a low level of soil bulk density $\left(1.19 \mathrm{~g} \cdot \mathrm{cm}^{-3}\right)$ [20].

The nutrient concentration recorded from fresh cattle manure was $8.50 \%$ organic carbon, $14.67 \%$ organic matter, $0.92 \%$ total nitrogen, $63.00 \mathrm{ppm}$ available phosphorus, $\left(45.15 \mathrm{cmol}(+) \mathrm{kg}^{-1}\right)$ cation exchange capacity, and $\mathrm{pH} 7.90$ (Table 2). Based on the values recorded, the $\mathrm{pH}$ of fresh cattle manure was moderately alkaline. In addition, the recorded values of total nitrogen, available phosphorus, organic carbon, and the cation exchange capacity of fresh cattle manure were very high according to the rating of [20].

2.2. Experimental Treatments and Design. Factorial combinations of two biofertilizer inoculants (without biofertilizer (B1), SB12 (B2), MAR1495 (B3), and SB12 plus MAR1495 biofertilizers at their recommended rates (B4); two organic fertilizers: without fresh cattle manure (M1) and fresh cattle manure at $10 \mathrm{t} \cdot \mathrm{ha}^{-1}$ (M2); two lime rates: without lime (L1) and lime at $5 \mathrm{t} \cdot \mathrm{ha}^{-1}$ (L2); two inorganic NPSB fertilizers: NPSB at 9.5-23-3.5-0.05 (F1) and NPSB at 19-46-7-0.1 (F2) at their recommended rates for soybean) were laid out in a randomized complete block design (RCBD) with three replications. The recommended rates of $\mathrm{N}, \mathrm{P}_{2} \mathrm{O}_{5}, \mathrm{~S}$, and $\mathrm{B}$ are $19 \mathrm{~kg} \cdot \mathrm{ha}^{-1}, 46 \mathrm{~kg} \cdot \mathrm{ha}^{-1}, 7 \mathrm{~kg} \cdot \mathrm{ha}^{-1}$, and $0.1 \mathrm{~kg} \cdot \mathrm{ha}^{-1}$, respectively, for soybean in the study areas. The sources of NPSB were $100 \mathrm{~kg}$ NPS ( $19 \% \mathrm{~N}, 46 \% \mathrm{P}_{2} \mathrm{O}_{5}$, and $\left.7 \% \mathrm{~S}\right), 17.4 \mathrm{~kg}$ TSP $\left(46 \% \mathrm{P}_{2} \mathrm{O}_{5}\right)$, and $1 \mathrm{~kg}$ borax $(0.1 \% \mathrm{~B})$. The improved soybean variety "Gishama" was used as a planting material. There were $2 \times 2 \times 2 \times 2=16$ treatment combinations, which were replicated three times and were constituted 48 experimental plots having the gross plot size of $3 \mathrm{~m} \times 2 \mathrm{~m}\left(6 \mathrm{~m}^{2}\right)$ and the net plot size of $2.4 \mathrm{~m} \times 1.9 \mathrm{~m}\left(4.56 \mathrm{~m}^{2}\right)$. Within the net plot, there were five planting rows. The spacing between rows was $60 \mathrm{~cm}$, while the spacing between plants was $5 \mathrm{~cm}$. Adjacent plots and blocks were separated by 0.5 and $1 \mathrm{~m}$, respectively.

2.3. Experimental Procedures. Prior to sowing, the land was finely plowed and harrowed manually. Seeds were inoculated prior to drilling with an inoculum of SB12and
TABLE 2: Chemical composition of fresh cattle manure.

\begin{tabular}{|c|c|c|}
\hline Chemical properties & Value & Rating \\
\hline $\mathrm{pH}\left(\mathrm{H}_{2} \mathrm{O}\right)$ & 7.90 & Moderately alkaline* \\
\hline Total nitrogen (\%) & 0.92 & Very high* \\
\hline Available P (ppm) & 63.00 & Very high* \\
\hline Organic carbon (\%) & 8.50 & Very high* \\
\hline CEC (meq $100 \mathrm{~g} \mathrm{soil}^{-1}$ ) & 45.15 & Very high* \\
\hline
\end{tabular}

${ }^{*}$ According to [20]. $\mathrm{CEC}=$ cation exchange capacity; $\mathrm{P}=$ phosphorus; $\mathrm{ppm}=$ part per million; $\mathrm{pH}=$ power of hydrogen .

MAR1495@500 g.ha ${ }^{-1}$ of each inoculum as per treatments. With regard to inoculation procedures, initially, 125 gram of sugar was applied to 1.25 liters of water and was heated for 15 minutes. Consequently, 500 gram of SB12 and 500 gram of MAR1495 were added and mixed into the above sugar suspension to form single inoculums. Then, the recommended rate of seed $\left(80 \mathrm{~kg} \cdot \mathrm{ha}^{-1}\right)$ was added to the above slurry of single inoculums and mixed by hand. Finally, the inoculated seed was dried in a shade on a plastic sheet for 15 minutes and was sown on furrows within 24 hours [21]. Inorganic fertilizers were applied as per the treatments. As per the recommendation, fresh cattle manure was prepared and applied 21 days before sowing. The reason for applying fresh cattle manure instead of well-rotten farm yard manure could be due to the higher nutrient concentration found in fresh cattle manure. Again, as per the recommendation, lime $\left(\mathrm{CaCO}_{3}\right)$ was broad casted and thoroughly mixed with the soil manually by hand 21 days before sowing. Soon after seeding, the furrows were covered by soils. Besides, all other agronomic practices for the soybean crop were performed as per the recommendation. Finally, the data were collected following the appropriate procedures.

2.4. Soil Sampling and Analysis. Soil samples were collected at a plow depth of $0-20 \mathrm{~cm}$ before sowing (one composite) and after harvesting of the crop (from each plot) for the analysis of major soil parameters. Disturbed soil samples of $1 \mathrm{~kg}$ were collected using an augur for the determination of various soil properties, while undisturbed soil samples were collected using a core sampler to determine soil bulk density. 
Soil samples of $1 \mathrm{~kg}$ were collected from 12 spots of the experimental land in a block and thoroughly mixed to form a composite sample, indicating that 12 spots represent a certain amount of area instead of using a single plot. Samples were then air dried and passed through $0.5 \mathrm{~mm}$ mesh sieve and packaged for laboratory analyses [22]. Soil texture was analyzed by the Bouyoucos hydrometer method following the procedure described by [23], while the bulk density was determined using the core method [24]. Soil $\mathrm{pH}$ was measured using a digital $\mathrm{pH}$ meter in a $1: 2.5$ soil-water suspension. Soil organic carbon content (OC) was determined by the wet digestion method [25]. Determination of total N was done using the Kjeldahl digestion method [24]. Available P was analyzed by the Olsen method using a mixture solution of $\mathrm{HCl}$ and $\mathrm{NH}_{4} \mathrm{~F}$ solution spectrophotometer [26]. Exchangeable bases $(\mathrm{Ca}, \mathrm{Mg}, \mathrm{K}$, and $\mathrm{Na}$ ) were determined after extracting the soil samples by $1.0 \mathrm{M}$ ammonium acetate $(\mathrm{NH} 4 \mathrm{OAc})$ extract at $\mathrm{pH} 7.0$, and the cation exchange capacity (CEC) was determined using the titration method.

\subsection{Fresh Cattle Manure Sampling and Analysis. Before the} application of fresh cattle manure to the experimental plots, samples of $1 \mathrm{~kg}$ fresh cattle manure were collected from the source and stored in plastic bags. Then, it was air dried and ground to pass through a $2 \mathrm{~mm}$ sieve and packaged for laboratory analyses. Then after, $\mathrm{pH}$, total $\mathrm{N}$, available $\mathrm{P}$, organic carbon, and cation exchange capacity in the fresh cattle manure were determined according to methods described in [22].

2.6. Crop Data Collection. Data of effective nodules per plant, leaf area index, and grain yield of soybean were collected following their respective standard methods and procedures. To determine effective nodules, five plants were randomly sampled from destructive rows of each experimental plot at $50 \%$ flowering stage (mid-flowering stage) of the plant. Then after, selected samples were randomly uprooted by carefully digging around the plant using a spade. Then, it was washed with clean tap water to remove all attached soil from the roots and the nodules. The nodules were then detached from the roots and dissect each nodule to identify effective nodules. Then, the cross section of the nodules was observed to identify the effectiveness of the nodules. When the colors were pink to dark red, it was considered as effective, while green, brown, or white color means ineffective nodules. Finally, the total number of effective nodules per plant was counted.

To measure the leaf area index, field photograph pictures were taken using a digital camera in typical growth stages at initial flower stage. The pictures were then imported immediately to the computer for analysis of leaf area index by using a leaf area index calculator called Hemisphere software [27]. Soybean plants were harvested at physiological maturity just above ground level from net plot area to determine grain yield. Then, the grain yield was recorded per plot and converted to hectare basis, and the average yield was expressed in kilogram per hectare after adjusting the grain yield by $10 \%$ moisture content.
2.7. Data Analysis. The data were further subjected to analysis of variance (ANOVA) using SAS version 9.1.3 [28]. For parameters whose ANOVA results showed significant differences between treatments, mean separation was done using DMRT at $1 \%$ or $5 \%$ level of probability.

2.8. Economic Analysis. Economic analysis was determined using the method described in [29]. The variable costs including seed, biofertilizers, fresh cattle manure, fertilizers (urea, TSP, NPS, and borax), lime $\left(\mathrm{Caco}_{3}\right)$, labor cost for weeding, labor cost for land preparation, labor cost for harvesting, and labor cost for threshing were recorded and used for analysis. The gross benefit was calculated as average adjusted grain yield $\left(\mathrm{kg} \mathrm{N} \cdot \mathrm{ha}^{-1}\right)$ and straw yield $\left(\mathrm{kg} \mathrm{N} \cdot \mathrm{ha}^{-1}\right)$ multiplied by field price that farmers receive for the sale of the crop. Net benefit was calculated by subtracting the total variable cost from the gross benefit.

\section{Results and Discussion}

3.1. Effective Nodules per Plant. The interaction effect of biofertilizers, organic fertilizers, lime, and inorganic fertilizers highly $(P<0.01)$ affected the number of effective nodules per plant at both locations and years (Table 3 ). Thus, in 2019, the interaction of SB12 + MAR1495, $10 \mathrm{t}^{\mathrm{h}} \mathrm{ha}^{-1}$ fresh cattle manure, $5 \mathrm{t} \cdot \mathrm{ha}^{-1}$ lime, and NPSB at 19-46-7-0.1 gave the maximum number of effective nodules per plant of 40.67 and 49.33 at Assosa and Bambassi, respectively; however, the interaction of uninoculated, without fresh cattle manure, without lime, and NPSB at 9.5-23-3.5-0.05 gave the minimum number of effective nodules per plant of 1.33 and 1.67 at Assosa and Bambassi, respectively. Whereas, in 2020, the interaction of SB12 + MAR1495, $10 \mathrm{t} / \mathrm{ha}$ fresh cattle manure, $5 \mathrm{t} \cdot \mathrm{ha}^{-1}$ lime, and NPSB at 19-46-7-0.1 gave the maximum number of effective nodules per plant of 52.67 and 58.33 at Assosa and Bambassi, respectively; however, the interaction of uninoculated, without fresh cattle manure, without lime, and NPSB at 9.5-23-3.5-0.05 gave the minimum number of effective nodules per plant of 2.33 and 2.00 at Assosa and Bambassi, respectively.

Generally, the maximum number of effective nodules per plant was recorded from the interaction of SB12 + MAR1495, $10 \mathrm{t} \cdot \mathrm{ha}^{-1}$ fresh cattle manure, $5 \mathrm{t} \cdot \mathrm{ha}^{-1}$ lime, and NPSB at 19-46-7-0.1, while the minimum number of effective nodules per plant was recorded from the interaction of uninoculated, without fresh cattle manure, without lime, and NPSB at 9.5-23-3.5-0.05 (Table 3). The increase in the number of effective nodules per plant might be due to the availability of optimum nutrients obtained from the combined sources. The maximum number of nodules per plant might be also due to the addition of lime in combination with biofertilizers, organic fertilizer, and inorganic fertilizer, which played a significant role in reducing acidity and therefore creating a favorable condition for survival of rhizobia and increasing the availability of nutrients. As a result, the available nutrients and the effective rhizobia in turn might hasten effective nodulation and the above ground biomass of soybean. This result is in agreement with the 


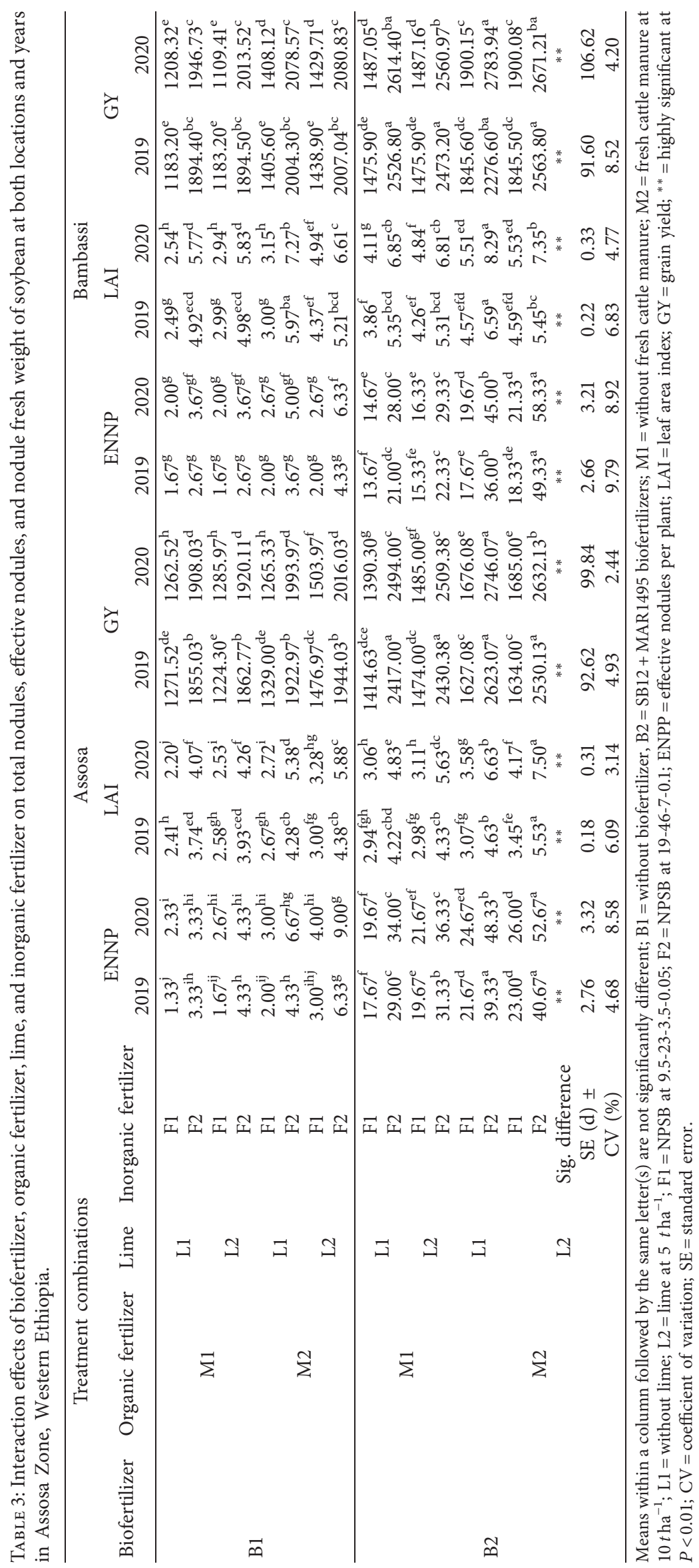


finding of Jones [13] who reported that the combined application of manure, lime, and inorganic fertilizer on inoculated soybean produced the highest nodule number, effective nodules, nodule fresh weight, nodule dry weight, and nodule volume per plant. The result is also similar to that by Bambara and Ndakidemi [14] who reported that the combined application of biofertilizers, organic fertilizers, lime, and inorganic fertilizers increased all the nodulation parameters of soybean.

3.2. Leaf Area Index. The interaction effect of biofertilizer, organic fertilizer, lime, and inorganic fertilizers highly $(P<0.01)$ affected the leaf area index at both locations and years (Table 3). Accordingly, the interaction of SB12 + MAR1495, 10 th $\mathrm{a}^{-1}$ fresh cattle manure, without lime, and NPSB at 19-46-7-0.1 gave the maximum leaf area index of 6.59 at Bambassi in 2019. On the other hand, the interaction of SB12 + MAR1495, $10 \mathrm{t} \cdot \mathrm{ha}^{-1}$ fresh cattle manure, $5 \mathrm{t} \cdot \mathrm{ha}^{-1}$ lime, and NPSB at 19-46-7-0.1 gave the maximum leaf area index of 5.53 at Assosa in 2019. However, the interaction of uninoculated, without fresh cattle manure, without lime, and NPSB at 9.5-23-3.5-0.05 gave the minimum leaf area index of 2.41 and 2.49 at Assosa and Bambassi, respectively.

In 2020, the interaction of SB12+MAR1495, $10 \mathrm{t} \cdot \mathrm{ha}^{-1}$ fresh cattle manure, without lime, and NPSB at 1946-7-0.1 gave the maximum leaf area index of 8.29 at Bambassi. On the other hand, the interaction of SB12 + MAR1495, $10 \mathrm{t} \cdot \mathrm{ha}^{-1}$ fresh cattle manure, $5 \mathrm{t} \cdot \mathrm{ha}^{-1}$ lime, and NPSB at 19-46-7-0.1 gave the maximum leaf area index of 7.50 at Assosa in 2020. However, the interaction of uninoculated, without fresh cattle manure, without lime, and NPSB at 9.5-23-3.5-0.05 gave the minimum leaf area index of 2.20 and 2.54 at Assosa and Bambassi, respectively.

Hence, in both years, the interaction of SB12 + MAR1495, $10 \mathrm{t} \cdot \mathrm{ha}^{-1}$ fresh cattle manure, $5 \mathrm{t} \cdot \mathrm{ha}^{-1}$ lime, and NPSB at 19-46-7-0.1 and the interaction of SB12 + MAR1495, $10 \mathrm{t} \cdot \mathrm{ha}^{-1}$ fresh cattle manure, without lime, and NPSB at 19-46-7-0.1 gave the maximum leaf area index at Assosa and Bambassi, respectively. The variation in the leaf area index across locations and the interactions might be due to the variation in initial soil conditions, temperature, and the rainfall of locations. Generally, the maximum leaf area index (8.29) was recorded from the interaction of SB12 + MAR1495, $10 \mathrm{t} \cdot \mathrm{ha}^{-1}$ fresh cattle manure, without lime, and NPSB at 19-46-7-0.1, while the minimum leaf area index (1.94) was recorded from the interaction of uninoculated, without fresh cattle manure, without lime, and NPSB at 9.5-23-3.5-0.05. The observed highest leaf area index might be due to the availability of optimum nutrients obtained from the combined sources. However, the combined application of lime with biofertilizers, organic fertilizers, and inorganic fertilizers did not bring a significant change on the leaf area index of soybean. This might be due to the nutrients obtained from the combined sources might have a liming effect, and as a result, it might not need any additional application of lime. This might be also due to the nutrients obtained from biofertilizers, organic fertilizers, and inorganic fertilizers in combination with the nutrients available in soil, which might be enough for leaf area development and hence may not need any additional support of lime. This result is in agreement with the finding of Shirpurkar et al. [15] who also reported that the integrated application of biofertilizers, fresh cattle manure at $10 \mathrm{t} \cdot \mathrm{ha}^{-1}$, and inorganic fertilizers at their recommended doses increased the values of leaf area index, total dry matter, pod length, number of pods per plant, seeds per pod, and hundred seed weight and ultimately increased the grain yield and harvest index of soybean.

3.3. Grain Yield. The interaction effect of biofertilizer, organic fertilizer, lime and inorganic fertilizer highly $(P<0.01)$ affected the grain yield at both locations and years (Table 3 ). As a result, the interaction of SB12+MAR1495, $10 \mathrm{t} \cdot \mathrm{ha}^{-1}$ fresh cattle manure, $5 \mathrm{t} \cdot \mathrm{ha}^{-1}$ lime, and NPSB at 1946-7-0.1 gave the maximum grain yield of $2563.80 \mathrm{~kg}$ at Bambassi, while the interaction of SB12+MAR1495, $10 \mathrm{t} \cdot \mathrm{ha}^{-1}$ fresh cattle manure, without lime, and NPSB at 1946-7-0.1 gave the maximum grain yield of $2623.07 \mathrm{~kg}$ at Assosa in 2019. However, the interaction of uninoculated, without fresh cattle manure, $5 \mathrm{t} \cdot \mathrm{ha}^{-1}$ lime, and NPSB at 9.523-3.5-0.05 gave the minimum grain yield of $1224.30 \mathrm{~kg}$ and $1183.20 \mathrm{~kg}$ at Assosa and Bambassi, respectively. Besides, the interaction of uninoculated, without fresh cattle manure, without lime, and NPSB at 9.5-23-3.5-0.05 gave the minimum grain yield of $1183.20 \mathrm{~kg}$ at Bambassi in 2019. Whereas, in 2020, the interaction effect of SB12 + MAR1495, $10 \mathrm{t}^{-\mathrm{ha}^{-1}}$ fresh cattle manure, without lime, and NPSB at 19-46-7-0.1 gave the maximum grain yield of $2746.07 \mathrm{~kg}$ and $2783.94 \mathrm{~kg}$ at Assosa and Bambassi, respectively. However, the interaction of uninoculated, without fresh cattle manure, $5 \mathrm{t} \cdot \mathrm{ha}^{-1}$ lime, and NPSB at 9.5-23-3.5-0.05 gave the minimum grain yield of $1109.41 \mathrm{~kg}$ and $1197.69 \mathrm{~kg}$ at Bambassi, while the interaction of uninoculated, without fresh cattle manure, without lime, and NPSB at 9.5-23-3.5-0.05 gave the minimum grain yield of $1262.52 \mathrm{~kg}$ at Assosa.

Generally, at both locations, the maximum grain yield was recorded from the interaction of SB12 + MAR1495, $10 \mathrm{t} \cdot \mathrm{ha}^{-1}$ fresh cattle manure, without lime, and NPSB at 1946-7-0.1, while the minimum grain yield was recorded from the interaction of uninoculated, without fresh cattle manure, $5 \mathrm{t} \cdot \mathrm{ha}^{-1}$ lime, and NPSB at 9.5-23-3.5-0.05. The observed increase in grain yield might be due to the availability of optimum nutrients obtained from the combined sources. However, the combined application of lime with biofertilizers, organic fertilizers, and chemical fertilizers did not bring a significant change on the grain yield of soybean. This might be due to the nutrients obtained from the combined sources that might have a liming effect and hence might not need any additional application of lime. This might be also due to the nutrients obtained from biofertilizers, organic fertilizers, and chemical fertilizers in combination with the nutrients available in soil, which might be enough for increasing the grain yield of soybean and hence may not need any additional support of lime. This result is in line with the 
finding of Shirpurkar et al. [15] who also reported that the integrated application of biofertilizers, fresh cattle manure at $10 \mathrm{tha}^{-1}$, and inorganic fertilizer at their recommended doses increased the values of leaf area index, total dry matter, pod length, number of pods per plant, seeds per pod, and hundred seed weight and ultimately increased the grain yield and harvest index of soybean.

3.4. Economic Analysis. Data presented in Table 4 indicate the economic analysis of soybean as affected by biofertilizer, organic fertilizer, lime, and inorganic fertilizer at both locations and years. It is clear from the data that the interaction of SB12, $10 \mathrm{t} \cdot \mathrm{ha}^{-1}$ fresh cattle manure, without lime, and NPSB fertilizer at 19-46-7-0.1 gave the maximum net income of $\mathrm{Br}$. 31,905.0, while the interaction of uninoculated, $10 \mathrm{t} \cdot \mathrm{ha}^{-1}$ fresh cattle manure, $5 \mathrm{t} \cdot \mathrm{ha}^{-1}$ lime, and NPSB fertilizer at 9.5-23-3.5-0.05 gave the minimum net income of Br.11, 148.0 at Assosa. Unlike Assosa, the maximum net income of Br. 33,465.3 was recorded from the interaction of SB12, without fresh cattle manure, without lime, and NPSB fertilizer at 19-46-7-0.1, while the minimum net income of Br. 9,935.05 was recorded from the interaction of uninoculated, without fresh cattle manure, $5 \mathrm{t} \cdot \mathrm{ha}^{-1}$ lime, and NPSB fertilizer at 9.5-23-3.5-0.05 at Bambassi.

The data further showed that the interaction of SB12, without fresh cattle manure, without lime, and NPSB at 1946-7-0.1 gave the maximum benefit cost ratio of 3.88, while the interaction of uninoculated, $10 \mathrm{t} \cdot \mathrm{ha}^{-1}$ fresh cattle manure, $5 \mathrm{t} \cdot \mathrm{ha}^{-1}$ lime, and NPSB at 9.5-23-3.5-0.05 gave the minimum benefit cost ratio of 0.76 at Assosa. Likewise, the maximum benefit cost ratio of 4.09 was recorded from the interaction of SB12, without fresh cattle manure, without lime, and NPSB at 19-46-7-0.1, while the minimum benefit cost ratio of 0.74 was recorded from the interaction of uninoculated, $10 \mathrm{t} \cdot \mathrm{ha}^{-1}$ fresh cattle manure, $5 \mathrm{t} \cdot \mathrm{ha}^{-1}$ lime, and NPSB at 9.5-23-3.5-0.05 at Bambassi.

\subsection{Effect of Bio-, Organic, and Inorganic NPSB Fertilizers and Lime on Soil Physicochemical Properties after Two Years of Experiment}

3.5.1. Bulk Density. The interaction effect of biofertilizer, organic fertilizer, lime, and inorganic fertilizers highly $(P<0.01)$ affected the bulk density at both locations (Table 5). Thus, the interaction of SB12+MAR1495, $10 \mathrm{t} \cdot \mathrm{ha}^{-1} \mathrm{FCM}, 5 \mathrm{t} \cdot \mathrm{ha}^{-1}$ lime, and NPSB at 19-46-7-0.1 gave the maximum bulk density of $1.18 \mathrm{~g} / \mathrm{cm}^{3}$ and $1.25 \mathrm{~g} / \mathrm{cm}^{3}$ at Assosa and Bambassi, respectively. However, the interaction of uninoculated, without FCM, without lime, and NPSB at 9.5-23-3.5-0.05 and the interaction of SB12 + MAR1495, without FCM, without lime, and NPSB at 9.5-23-3.5-0.05 gave the minimum bulk density of $1.14 \mathrm{~g} / \mathrm{cm}^{3}$ and $1.21 \mathrm{~g} / \mathrm{cm}^{3}$ at Assosa and Bambassi, respectively.

Generally, the interaction of SB12 + MAR1495, $10 \mathrm{t}^{\mathrm{h}} \mathrm{ha}^{-1}$ FCM, 5 th ha ${ }^{-1}$ lime, and NPSB at 19-46-7-0.1 improved the bulk density of the soil compared with sole application of biofertilizer, organic fertilizer, inorganic fertilizer, and lime at both locations. This might be due to the availability of balanced nutrients obtained from the combined sources. The balanced nutrients obtained from the combined sources might have a contribution in enhancing the formation and stabilization of soil aggregates. The formation of soil aggregates increased soil porosity and hence lowered soil compaction or bulk density. This result is in line with Zhang et al. [30] who reported that the combined application of soil amendments enhances the stability of soil aggregation and has a positive significant effect on a range of soil physical properties and functions, which results in improved total soil porosity and permeability and, because of that, lowered soil compaction or soil bulk density.

3.5.2. $p H$. The interaction effect of biofertilizer, organic fertilizer, lime, and inorganic fertilizers highly $(P<0.01)$ affected the $\mathrm{pH}$ at both locations (Table 5). Thus, the interaction of SB12 + MAR1495, $10 \mathrm{t} \cdot \mathrm{ha}^{-1} \mathrm{FCM}, 5 \mathrm{t} \cdot \mathrm{ha}^{-1}$ lime, and NPSB at 19-46-7-0.1 gave the maximum $\mathrm{pH}$ of 5.45 and 5.56 at Assosa and Bambassi, respectively. However, the interaction of uninoculated, without FCM, without lime, and NPSB at 9.5-23-3.5-0.05 gave the minimum $\mathrm{pH}$ of 5.09 and 5.29 at Assosa and Bambassi, respectively.

Generally, the interaction of SB12 + MAR1495, $10 \mathrm{t} \cdot \mathrm{ha}^{-1}$ FCM, $5 \mathrm{t} \cdot \mathrm{ha}^{-1}$ lime, and NPSB at 19-46-7-0.1 improved the $\mathrm{pH}$ of the soil compared with sole application of biofertilizer, organic manure, inorganic fertilizer, and lime at both locations. This might be due to the availability of higher calcium and magnesium obtained from the combined sources. The presence of higher calcium and magnesium displaces $\mathrm{H}+, \mathrm{Fe} 2+, \mathrm{Al} 3+$, and $\mathrm{Mn} 4+$ ions from the soil adsorption site and hence increases soil $\mathrm{pH}$. This result is in line with the findings of Onwonga et al. [31] who reported that the application of lime tends to raise the soil $\mathrm{pH}$ by the displacement of $\mathrm{H}+, \mathrm{Fe} 2+, \mathrm{Al} 3+$, and $\mathrm{Mn} 4+$ ions from the soil adsorption site and subsequent neutralization of $\mathrm{H}+$ and precipitation of $\mathrm{Fe}, \mathrm{Al}$, and $\mathrm{Mn}$ as hydroxides.

3.5.3. Total Nitrogen. The interaction effect of biofertilizer, organic fertilizer, lime, and inorganic fertilizers highly $(P<0.01)$ affected the total nitrogen at both locations $(\mathrm{Ta}-$ ble 5). Thus, the interaction of SB12 + MAR1495, $10 \mathrm{t} \cdot \mathrm{ha}^{-1}$ FCM, $5 \mathrm{t} \cdot \mathrm{ha}^{-1}$ lime, and NPSB at 19-46-7-0.1 gave the maximum total nitrogen of 0.55 and 0.84 at Assosa and Bambassi, respectively. However, the interaction of uninoculated, without FCM, without lime, and NPSB at 9.5-233.5-0.05 gave the minimum total nitrogen of 0.15 and 0.44 at Assosa and Bambassi, respectively.

Generally, the interaction of SB12 + MAR1495, $10 \mathrm{t} \cdot \mathrm{ha}^{-1}$ FCM, $5 \mathrm{t} \cdot \mathrm{ha}^{-1}$ lime, and NPSB at 19-46-7-0.1 improved the total nitrogen in the soil compared with sole application of biofertilizer, organic fertilizer, inorganic fertilizer, and lime at both locations. This might be due to the availability of higher nitrogen obtained from the combined sources. This result is in agreement with the finding of Kaur [32] who reported that the significant increase in total nitrogen was observed in treatments having combined application of biofertilizers, inorganic fertilizers, organic fertilizers, and lime. Kumar and Shivay [33] also revealed that integrated 


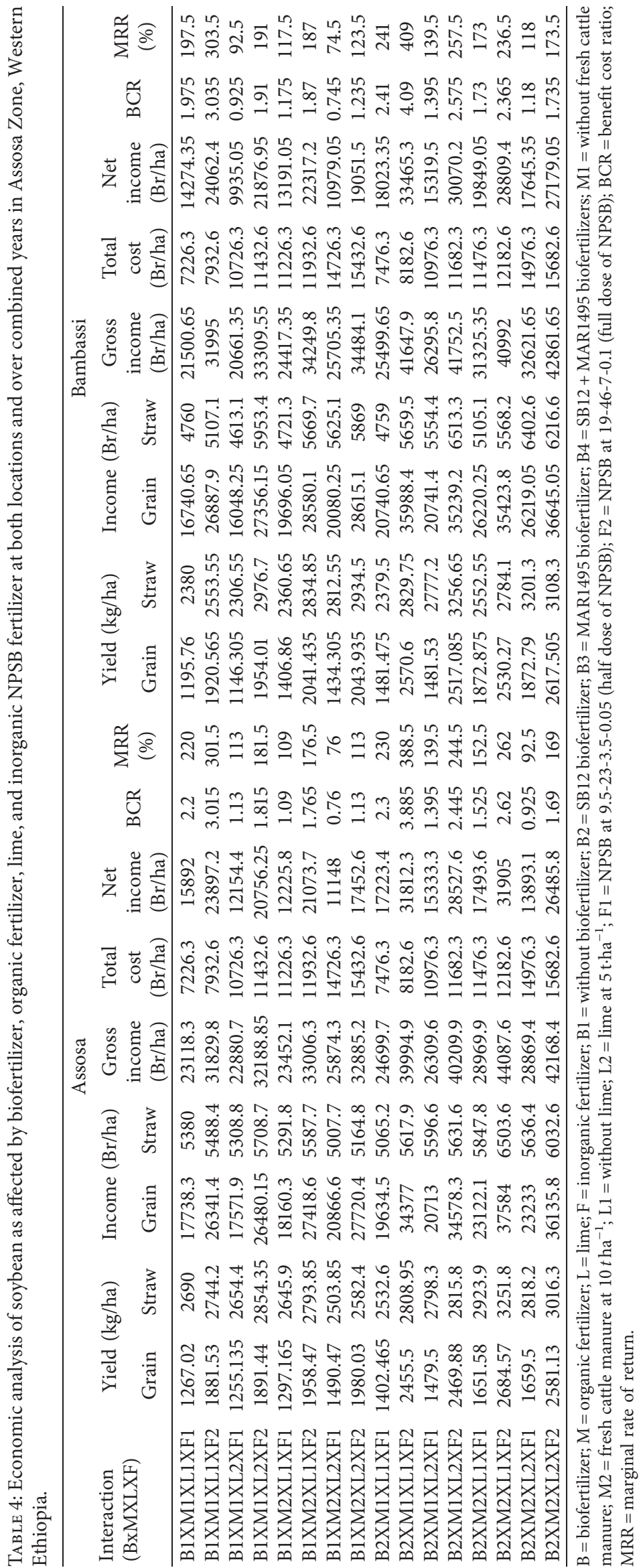


TABLE 5: Interaction effects of biofertilizer, organic manure, inorganic NPSB fertilizer, and lime on soil physicochemical properties after two years of experiment at both locations in Assosa Zone, Western Ethiopia.

\begin{tabular}{|c|c|c|c|c|c|c|c|c|c|c|c|c|c|c|c|}
\hline \multicolumn{4}{|c|}{ Treatment combination } & \multicolumn{6}{|c|}{ Assosa } & \multicolumn{6}{|c|}{ Bambassi } \\
\hline Biofertilizer & $\begin{array}{l}\text { Organic } \\
\text { manure }\end{array}$ & Lime & $\begin{array}{l}\text { Inorganic } \\
\text { fertilizer }\end{array}$ & $\mathrm{BD}$ & $\mathrm{pH}$ & $\mathrm{TN}$ & AVP & $\mathrm{OC}$ & CEC & $\mathrm{BD}$ & $\mathrm{pH}$ & $\mathrm{TN}$ & AVP & $\mathrm{OC}$ & CEC \\
\hline \multirow{8}{*}{ B1 } & \multirow{4}{*}{ M1 } & \multirow[b]{2}{*}{ L1 } & $\mathrm{F} 1$ & $1.14^{\mathrm{g}}$ & $5.09^{\mathrm{h}}$ & $0.15^{1}$ & $5.57^{\mathrm{h}}$ & $2.54^{\mathrm{f}}$ & $21.40^{\mathrm{h}}$ & $1.21^{\mathrm{g}}$ & $5.29^{\mathrm{d}}$ & $0.44^{1}$ & $4.79^{\mathrm{h}}$ & $3.06^{f}$ & $24.91^{\mathrm{f}}$ \\
\hline & & & $\mathrm{E} 2$ & $1.15^{\mathrm{f}}$ & $5.10^{\mathrm{g}}$ & $0.17^{\mathrm{k}}$ & $6.18^{\mathrm{g}}$ & $2.55^{\mathrm{e}}$ & $21.37^{\mathrm{g}}$ & $1.22^{\mathrm{f}}$ & $5.30^{\mathrm{d}}$ & $0.46^{\mathrm{k}}$ & $5.00^{\mathrm{g}}$ & $3.07^{\mathrm{e}}$ & $24.92^{\mathrm{g}}$ \\
\hline & & \multirow{2}{*}{ L2 } & $\mathrm{F} 1$ & $1.15^{\mathrm{e}}$ & $5.36^{\mathrm{d}}$ & $0.18^{j}$ & $6.76^{\mathrm{f}}$ & $2.55^{\mathrm{e}}$ & $21.36^{\mathrm{f}}$ & $1.22^{\mathrm{e}}$ & $5.54^{\mathrm{c}}$ & $0.47^{\mathrm{j}}$ & $5.42^{\mathrm{f}}$ & $3.07^{\mathrm{e}}$ & $24.91^{\mathrm{f}}$ \\
\hline & & & $\mathrm{F} 2$ & $1.15^{\mathrm{d}}$ & $5.34^{\mathrm{e}}$ & $0.21^{\mathrm{g}}$ & $6.91^{\mathrm{e}}$ & $2.55^{\mathrm{e}}$ & $21.37^{\mathrm{e}}$ & $1.22^{\mathrm{d}}$ & $5.54^{\mathrm{c}}$ & $0.50^{\mathrm{g}}$ & $5.52^{\mathrm{e}}$ & $3.07^{\mathrm{e}}$ & $24.92^{\mathrm{e}}$ \\
\hline & \multirow{4}{*}{ M2 } & \multirow[b]{2}{*}{ L1 } & $\mathrm{F} 1$ & $1.17^{\mathrm{c}}$ & $5.33^{\mathrm{f}}$ & $0.19^{\mathrm{i}}$ & $6.93^{\mathrm{d}}$ & $2.83^{\mathrm{d}}$ & $22.12^{\mathrm{d}}$ & $1.24^{\mathrm{c}}$ & $5.53^{\mathrm{b}}$ & $0.48^{\mathrm{i}}$ & $5.55^{\mathrm{d}}$ & $3.35^{\mathrm{d}}$ & $25.66^{\mathrm{d}}$ \\
\hline & & & $\mathrm{F} 2$ & $1.17^{\mathrm{b}}$ & $5.37^{\mathrm{c}}$ & $0.20^{\mathrm{h}}$ & $7.04^{\mathrm{c}}$ & $2.84^{\mathrm{c}}$ & $22.24^{\mathrm{c}}$ & $1.24^{\mathrm{b}}$ & $5.53^{\mathrm{b}}$ & $0.49^{\mathrm{h}}$ & $5.64^{\mathrm{c}}$ & $3.36^{\mathrm{c}}$ & $25.79^{\mathrm{c}}$ \\
\hline & & \multirow{2}{*}{ L2 } & $\mathrm{F} 1$ & $1.18^{\mathrm{a}}$ & $5.42^{\mathrm{b}}$ & $0.22^{\mathrm{f}}$ & $7.14^{\mathrm{b}}$ & $3.11^{\mathrm{b}}$ & $23.30^{\mathrm{b}}$ & $1.25^{\mathrm{a}}$ & $5.55^{\mathrm{a}}$ & $0.51^{\mathrm{f}}$ & $5.74^{\mathrm{b}}$ & $3.63^{\mathrm{b}}$ & $26.85^{b}$ \\
\hline & & & F2 & $1.18^{\mathrm{a}}$ & $5.44^{\mathrm{a}}$ & $0.23^{\mathrm{e}}$ & $7.44^{\mathrm{a}}$ & $3.15^{\mathrm{a}}$ & $23.75^{\mathrm{a}}$ & $1.25^{\mathrm{a}}$ & $5.55^{\mathrm{a}}$ & $0.52^{\mathrm{e}}$ & $6.11^{\mathrm{a}}$ & $3.67^{\mathrm{a}}$ & $27.30^{\mathrm{a}}$ \\
\hline \multirow{11}{*}{ B2 } & \multirow{4}{*}{ M1 } & \multirow{2}{*}{ L1 } & F1 & $1.14^{\mathrm{g}}$ & $5.09^{\mathrm{h}}$ & $0.22^{\mathrm{f}}$ & $5.57^{\mathrm{h}}$ & $2.54^{\mathrm{f}}$ & $21.40^{\mathrm{h}}$ & $1.21^{\mathrm{g}}$ & $5.29^{\mathrm{d}}$ & $0.52^{\mathrm{e}}$ & $4.79^{h}$ & $3.06^{\mathrm{f}}$ & $24.91^{\mathrm{f}}$ \\
\hline & & & F2 & $1.15^{\mathrm{f}}$ & $5.10^{\mathrm{g}}$ & $0.24^{\mathrm{d}}$ & $6.18^{\mathrm{g}}$ & $2.55^{\mathrm{e}}$ & $21.37^{\mathrm{g}}$ & $1.22^{\mathrm{f}}$ & $5.30^{\mathrm{d}}$ & $0.53^{\mathrm{d}}$ & $5.00^{\mathrm{g}}$ & $3.07^{\mathrm{e}}$ & $24.92^{\mathrm{g}}$ \\
\hline & & \multirow{2}{*}{ L2 } & $\mathrm{F} 1$ & $1.15^{\mathrm{e}}$ & $5.36^{\mathrm{d}}$ & $0.24^{\mathrm{d}}$ & $6.76^{\mathrm{f}}$ & $2.55^{\mathrm{e}}$ & $21.36^{\mathrm{f}}$ & $1.22^{\mathrm{e}}$ & $5.54^{\mathrm{c}}$ & $0.53^{\mathrm{d}}$ & $5.42^{\mathrm{f}}$ & $3.07^{\mathrm{e}}$ & $24.91^{\mathrm{f}}$ \\
\hline & & & F2 & $1.15^{\mathrm{d}}$ & $5.34^{\mathrm{e}}$ & $0.25^{\mathrm{c}}$ & $6.91^{\mathrm{e}}$ & $2.55^{\mathrm{e}}$ & $21.37^{\mathrm{e}}$ & $1.22^{\mathrm{d}}$ & $5.54^{\mathrm{c}}$ & $0.54^{\mathrm{c}}$ & $5.52^{\mathrm{e}}$ & $3.07^{\mathrm{e}}$ & $24.92^{\mathrm{e}}$ \\
\hline & \multirow{7}{*}{ M2 } & \multirow{3}{*}{ L1 } & $\mathrm{F} 1$ & $1.17^{\mathrm{c}}$ & $5.33^{\mathrm{f}}$ & $0.24^{\mathrm{d}}$ & $6.93^{\mathrm{d}}$ & $2.83^{\mathrm{d}}$ & $22.12^{\mathrm{d}}$ & $1.24^{\mathrm{c}}$ & $5.53^{\mathrm{b}}$ & $0.53^{\mathrm{d}}$ & $5.55^{\mathrm{d}}$ & $3.35^{\mathrm{d}}$ & $25.66^{\mathrm{d}}$ \\
\hline & & & F2 & $1.17^{\mathrm{b}}$ & $5.37^{\mathrm{C}}$ & $0.25^{\mathrm{c}}$ & $7.04^{c}$ & $2.84^{\mathrm{c}}$ & $22.24^{\mathrm{c}}$ & $1.24^{\mathrm{b}}$ & $5.53^{\mathrm{b}}$ & $0.54^{\mathrm{c}}$ & $5.64^{\mathrm{c}}$ & $3.36^{\mathrm{c}}$ & $25.79^{c}$ \\
\hline & & & $\mathrm{F} 1$ & $1.18^{\mathrm{a}}$ & $5.42^{\mathrm{b}}$ & $0.36^{\mathrm{b}}$ & $7.15^{\mathrm{b}}$ & $3.10^{\mathrm{b}}$ & $23.30^{\mathrm{b}}$ & $1.25^{\mathrm{a}}$ & $5.55^{\mathrm{a}}$ & $0.65^{\mathrm{b}}$ & $5.74^{\mathrm{b}}$ & $3.61^{\mathrm{b}}$ & $26.85^{b}$ \\
\hline & & \multirow{4}{*}{ L2 } & $\mathrm{F} 2$ & $1.18^{\mathrm{a}}$ & $5.45^{\mathrm{a}}$ & $0.55^{\mathrm{a}}$ & $7.47^{\mathrm{a}}$ & $3.15^{\mathrm{a}}$ & $23.75^{\mathrm{a}}$ & $1.25^{\mathrm{a}}$ & $5.56^{\mathrm{a}}$ & $0.84^{\mathrm{a}}$ & $6.13^{\mathrm{a}}$ & $3.67^{\mathrm{a}}$ & $27.30^{\mathrm{a}}$ \\
\hline & & & Sig. difference & $* *$ & $* *$ & $* *$ & $* *$ & $* *$ & $* *$ & $* *$ & $* *$ & $* *$ & $* *$ & $* *$ & $* *$ \\
\hline & & & $\mathrm{SE}(\mathrm{d}) \pm$ & 0.003 & 0.02 & 0.01 & 0.19 & 0.07 & 0.16 & 0.003 & 0.02 & 0.01 & 0.13 & 0.07 & 0.16 \\
\hline & & & $\mathrm{CV}(\%)$ & 1.73 & 2.29 & 17.78 & 12.50 & 12.47 & 5.08 & 1.68 & 2.21 & 12.29 & 10.53 & 9.80 & 4.37 \\
\hline
\end{tabular}

Means within a column followed by the same letter(s) are not significantly different; B1 = without biofertilizer, B2=SB12+MAR1495 biofertilizers; $\mathrm{M} 1=$ without fresh cattle manure; M2 = fresh cattle manure at $10 \mathrm{t} \cdot \mathrm{ha}^{-1} ; \mathrm{L} 1=$ without lime; $\mathrm{L} 2=$ lime at $5 \mathrm{t} \cdot \mathrm{ha}^{-1} ; \mathrm{F} 1=\mathrm{NPSB}$ at 9.5-23-3.5-0.05; F2 = NPSB at 19-46-7-0.1; $\mathrm{BD}=$ bulk density; $\mathrm{pH}=$ power of hydrogen; $\mathrm{TN}=$ total nitrogen; $\mathrm{AVP}=$ available phosphorus; $\mathrm{OC}=$ organic carbon; $\mathrm{CEC}=$ cation exchange capacity; ${ }^{* *}=$ highly significant at $P<0.01 ; \mathrm{SE}=$ standard error; $\mathrm{CV}=$ coefficient of variation.

use of biofertilizers, organic fertilizers, inorganic fertilizers, and lime significantly improved the available $\mathrm{N}, \mathrm{P}$, and $\mathrm{K}$ contents compared with sole application of inorganic fertilizers.

3.5.4. Available Phosphorus. The interaction of biofertilizer, organic fertilizer, lime, and inorganic fertilizers highly $(P<0.01)$ affected the available phosphorus at both locations (Table 5). Thus, the interaction of SB12 + MAR1495, $10 \mathrm{t}^{\mathrm{ha}} \mathrm{h}^{-1}$ FCM, $5 \mathrm{t} \cdot \mathrm{ha}^{-1}$ lime, and NPSB at 19-46-7-0.1 gave the maximum available phosphorus of $7.47 \mathrm{ppm}$ and $6.13 \mathrm{ppm}$ at Assosa and Bambassi, respectively. However, the interaction of uninoculated, without FCM, without lime, and NPSB at 9.5-233.5-0.05 gave the minimum available phosphorus of $6.07 \mathrm{ppm}$ and $4.79 \mathrm{ppm}$ at Assosa and Bambassi, respectively.

Generally, the interaction of SB12 + MAR1495, $10 \mathrm{t}^{\mathrm{h}} \mathrm{ha}^{-1}$ FCM, $5 \mathrm{t}^{-h^{-1}}$ lime, and NPSB at 19-46-7-0.1 improved available phosphorus in the soil compared with sole application of biofertilizer, organic manure, inorganic fertilizer, and lime at both locations. This might be due to the availability of higher phosphorus obtained from the combined sources. This result is in agreement with the finding of Kassa et al. [34] who found that the combined application of fresh cattle manure with biofertilizers, inorganic fertilizers, and lime increased the amount of available phosphorus in soil, as it helps in sustaining higher population of several bacteria and fungi, which are capable of solubilizing soil phosphorus. Kumar and Shivay [33] also revealed that the integrated use of biofertilizers, organic fertilizers, inorganic fertilizers, and lime significantly improved the available N, P, and $\mathrm{K}$ contents compared with sole application of inorganic fertilizers.

3.5.5. Organic Carbon. The interaction effect of biofertilizer, organic fertilizer, lime, and inorganic fertilizers highly $(P<0.01)$ affected the organic carbon at both locations (Table 5). Thus, the interaction effect of SB12 + MAR1495, $10 \mathrm{t} \cdot \mathrm{ha}^{-1}$ FCM, $5 \mathrm{t} \cdot \mathrm{ha}^{-1}$ lime, and NPSB at 19-46-7-0.1 gave the maximum organic carbon of 3.15 and 3.67 at Assosa and Bambassi, respectively. However, the interaction effect of uninoculated, without FCM, without lime, and NPSB at 9.523-3.5-0.05 gave the minimum organic carbon of 2.54 and 3.06 at Assosa and Bambassi, respectively.

Generally, the interaction effect of SB12+MAR1495, $10 \mathrm{t} \cdot \mathrm{ha}^{-1} \mathrm{FCM}, 5 \mathrm{t} \cdot \mathrm{ha}^{-1}$ lime, and NPSB at 19-46-7-0.1 improved organic carbon in the soil compared with sole application of biofertilizer, organic fertilizer, inorganic fertilizer, and lime at both locations. The presence of higher organic carbon might be due to the synergetic effect of combined resources. This result is in agreement with the finding of $\mathrm{Li}$ et al. [35] who reported that the integrated use of organic manure and inorganic fertilizers along with biofertilizer and lime is a promising approach in preserving soil microbial communities and activities, which will ultimately show positive impacts on different soil physicochemical properties and crop production.

3.5.6. Cation Exchange Capacity. The interaction effect of biofertilizer, organic fertilizer, lime, and inorganic fertilizers 
highly $(P<0.01)$ affected the cation exchange capacity at both locations (Table 5). Thus, the interaction of SB12 + MAR1495, $10 \mathrm{t} \cdot \mathrm{ha}^{-1} \mathrm{FCM}, 5 \mathrm{t} \cdot \mathrm{ha}^{-1}$ lime, and NPSB at 19-46-7-0.1 gave the maximum cation exchange capacity of 23.75 and 27.30 at Assosa and Bambassi, respectively. However, the interaction of uninoculated, without FCM, without lime, and NPSB at 9.5-23-3.5-0.05 gave the minimum cation exchange capacity of 21.40 and 24.97 at Assosa and Bambassi, respectively.

Generally, the interaction effect of SB12 + MAR1495, $10 \mathrm{t} \cdot \mathrm{ha}^{-1}$ FCM, $5 \mathrm{t} \cdot \mathrm{ha}^{-1}$ lime, and NPSB at 19-46-7-0.1 improved the cation exchange capacity in the soil compared with sole application of biofertilizer, organic manure, inorganic fertilizer, and lime at both locations. This might be due to the availability of exchangeable cations obtained from the combined sources. This result is in line with the finding of Li et al. [35] who reported that the integrated use of organic manure and inorganic fertilizers along with biofertilizers and lime is a promising approach in preserving soil microbial communities and activities, which will ultimately show positive impacts on different soil physicochemical properties and crop production.

\section{Conclusion}

In conclusion, from this experiment it was noted that effective nodules per plant, leaf area index, grain yield, bulk density, $\mathrm{pH}$, total nitrogen, available phosphorus, organic carbon, and cation exchange capacity were highly $(P<0.01)$ affected by the interaction of bio-, organic, and inorganic fertilizers and lime at both locations and years. The highest number of effective nodules per plant was recorded from the interaction of SB12 + MAR1495, $10 \mathrm{t} \cdot \mathrm{ha}^{-1}$ fresh cattle manure, $5 \mathrm{t} \cdot \mathrm{ha}^{-1}$ lime, and NPSB fertilizer at 19-46-7-0.1. The highest leaf area index and grain yield were recorded from the interaction of SB12 + MAR1495, $10 \mathrm{t} \cdot \mathrm{ha}^{-1}$ fresh cattle manure, without lime, and NPSB at 19-46-7-0.1. Despite the individual role of biofertilizer, organic fertilizer, lime, and inorganic fertilizer, their interaction effects have more pronounced effects in maximizing the productivity of soybean. The maximum bulk density, $\mathrm{pH}$, total nitrogen, available phosphorus, organic carbon, and CEC were recorded from the interaction effect of SB12 + MAR1495, $10 \mathrm{t} \cdot \mathrm{ha}^{-1} \mathrm{FCM}, 5 \mathrm{t} \cdot \mathrm{ha}^{-1}$ lime, and NPSB at 19-46-7-0.1. Finally, the interaction of SB12 + MAR1495, $10 \mathrm{t} \cdot \mathrm{ha}^{-1}$ fresh cattle manure, without lime, and NPSB at 19-46-7-0.1 increased the grain yield of soybean at both Assosa and Bambassi districts and should be adopted appropriately to enhance the productivity of soybean in the areas and similar agroecologies, while the interaction effect of SB12 + MAR1495, $10 \mathrm{t} \cdot \mathrm{ha}^{-1} \mathrm{FCM}, 5 \mathrm{t} \cdot \mathrm{ha}^{-1}$ lime, and NPSB at 19-46-7-0.1 improved soil physicochemical properties in both the districts and similar agroecologies.

\section{Data Availability}

The data used to support the findings of this study are included within the article.

\section{Conflicts of Interest}

The authors declare that they have no conflicts of interest.

\section{Acknowledgments}

The authors are grateful to the Ministry of Science and Higher Education (MOSHE) for providing financial support to conduct this experiment. The authors are also thankful to Assosa University and Assosa Agricultural Research Center for providing necessary facilities to conduct this experiment.

\section{References}

[1] H. Tefera, "Breeding for promiscuous soybeans at IITA," in Soybean-Molecular Aspects of Breeding, A. Sudaric, Ed., InTech, Rijeka, Croatia, 2010, http://www.intechopen.com/ books/soybean-molecular-aspects-of-breeding/beeding-forpromiscuous-soybeans-at-iita.

[2] D. Zinaw, A. Seltene, and G. Addisu, "Genetic variability and heritability of soybean (Glycinemax (L.) Merrill) genotypes in Pawe district, Metekel zone, Benishangul Gumuz regional state, northwestern Ethiopia," Wudpecker J. Agric. Res.,vol. 2, no. 9, pp. 240-245, 2013.

[3] R. N. Collombet, Investigating Soybean Market Situation in Western Kenya: Constraints and Opportunities for Smallholder Producers, pp. 1-43, Wageningen University, Wageningen, Netherlands, 2013.

[4] I. Y. Dugje, O. LO, F. Ekeleme, R. Bandyopadhyay, P. L. Kumar, and A. Y. Kamara, Farmers Guide to Soybean Production in Northern Nigeria, pp. 1-16, International Institute of Tropical Agriculture, Ibadan, Nigeria, 2009.

[5] CSA (Central Statistics Agency of Ethiopia), Report on Area and Crop Production Forecast for Major Crops, CSA, Addis Ababa, Ethiopia, 2017.

[6] United states Department of Agriculture (USDA), Annual Report, United states Department of Agriculture (USDA), Washington, DC, USA, 2017.

[7] CSA (Central Statistics Agency of Ethiopia), Report on Area and Crop Production Forecast for Major Crops, CSA (Central Statistics Agency of Ethiopia), Addis Ababa, Ethiopia, 2018.

[8] T. R. Sinclair, H. Marrou, A. Soltani, V. Vadez, and K. C. Chandolu, "Soybean production potential in Africa," Global Food Security, vol. 3, no. 1, pp. 31-40, 2014.

[9] Assosa Agricultural Research Center (AsARC), Annual Report, Assosa Agricultural Research Center (AsARC), Assosa, Ethiopia, 2017.

[10] G. Zelleke, G. Agegnehu, D. Abera, and S. Rashid, Fertilizer and Soil Fertility Potential in Ethiopia: Constraints and Opportunities for Enhancing the System, International Food Policy Research Institute, Washington, D.C., USA, 2010.

[11] A. Dibabe, "Effect of fertilizer on the yield and nodulation pattern of faba bean on a Nitosol of Adet, North Western Ethiopia," Ethiopian Journal of Natural Resources, vol. 2, pp. 237-244, 2000.

[12] A. Khaliq and M. K. Abbasi, "Soybean Response to single or mixed soil amendments in Kashmir, Pakistan," Agronomy Journal, vol. 107, no. 3, pp. 887-895, 2015.

[13] J. B. Jones, Agronomic Handbook: Management of Crops, Soils, and Their Fertility, CRC Press LLC, Boca Raton, FL, USA, 2003.

[14] S. Bambara and P. A. Ndakidemi, "The potential roles of lime and molybdenum on the growth, nitrogen fixation and assimilation of metabolites in nodulated legume: a special 
reference to Phaseolus vulgaris L," African Journal of Biotechnology, vol. 8, pp. 2482-2489, 2010, Direct Link.

[15] G. N. Shirpurkar, N. V. Kashid, M. S. Kamble, and V. N. Gavhane, "Effect of application of different micronutrients on growth attributing characters of soybean (Glycine max)," Research on Crops, vol. 6, no. 2, pp. 225-228, 2005.

[16] A. O. Nekesa, J. R. Okalebo, C. O. Othieno, M. N. Thuita, A. Bationo, and B. S. Waswa, "The potential of increased maize and soybean production in uasin gishu district, Kenya, resulting from soil acidity amendment using minjingu phosphate rock and agricultural lime," in Innovations as Key to the Green Revolution in Africa, A. Bationo, Ed., Springer, Dordrecht, Dordrecht, Netherlands, 2011.

[17] G.-W. Rathke, O. Christen, and W. Diepenbrock, "Effects of nitrogen source and rate on productivity and quality of winter oilseed rape (Brassica napus L.) grown in different crop rotations," Field Crops Research, vol. 94, no. 2-3, pp. 103-113, 2005.

[18] J. R. Ross, N. A. Slaton, K. R. Brye, and R. E. DeLong, "Boron fertilization influences on soybean yield and leaf and seed boron concentrations," Agronomy Journal, vol. 98, no. 1, pp. 198-205, 2006.

[19] R. Singh and R. K. Rai, "Yield attributes, yield and quality of soybean as influenced by integrated nutrient management," Indian Journal of Agronomy, vol. 49, pp. 271-274, 2005.

[20] P. Hazelton and B. Murphy, Interpreting Soil Test Results: What Do All the Numbers Mean?, CSIRO Publishing, Clayton, Australia, 2nd Edition, 2007.

[21] P. Somasegaran and H. J. Hoben, Handbook for Rhizobia: Methods in Legume - Rhizobium Technology, p. 366, Springer - Verkag, New York, NY, USA, 1994.

[22] J. R. Okalebo, K. W. Gathua, and P. L. Woomer, Laboratory Methods of Plant and Soil Analysis: A Working Manual, TSBFUNESCO, Nairobi, Kenya, 2nd edition, 2002.

[23] G. J. Bouyoucos, "Hydrometer method improved for making particle size analyses of soils 1," Agronomy Journal, vol. 54, no. 5, pp. 464-465, 1962.

[24] G. R. Black, "Bulk density," in Methods of Analysis. Agronomy Part I, C. A. Black, Ed., no. 9, pp. 374-399, American Society of Agronomy, Madison, Wisconsin, 1965.

[25] A. Walkley and I. A. Black, "An examination of the degtjareff method for determining soil organic matter, and a proposed modification of the chromic acid titration method," Soil Science, vol. 37, no. 1, pp. 29-38, 1934.

[26] S. R. Olsen and L. E. Sommers, "Phosphorus," in Methods of Soil Analysis. Part 2. Chemical and Microbiological Properties, A. L. Page, Ed., pp. 403-430, American Society of Agronomy and Soil Science Society of America, Madison, WI, USA, Second edition, 1982.

[27] A. Thimonier, I. Sedivy, and P. Schleppi, "Estimating leaf area index in different types of mature forest stands in Switzerland: a comparison of methods," European Journal of Forest Research, vol. 129, no. 4, pp. 543-562, 2010.

[28] SAS (Statistical Analysis System) Institute, The SAS System for Windows, version 9.1.3, SAS Institute Inc., Cary, NC., USA, 2002.

[29] CIMMYT, From Agronomic Data to Farmer Recommendations: An Economics Work Book, pp. 1-63, The International Maize and Wheat Improvement Center, Mexico, 1988.

[30] H. Zhang, F. D’Aoust, T. C. Charles, B. T. Driscoll, B. Prithiviraj, and D. L. Smith, "Bradyrhizobium japonicum mutants allowing improved soybean yield in short season areas with cool spring soil temperatures," Crop Science, vol. 42, no. 4, pp. 1186-1190, 2002.
[31] R. N. Onwonga, J. J. Lelei, and B. B. Mochoge, "Mineral nitrogen and microbial biomass dynamics under different acid soil management practices for maize production," Journal of Agricultural Science, vol. 2, no. 1, p. 16, 2010.

[32] H. Kaur, Effect of Bio-Fertilizers and Organic Fertilizers on Soil Health, Growth and Yield of Green Pea (Pisum Sativum l.), Department of Microbiology College of Basic Sciences and Humanities (C) Punjab agricultural university Ludhiana -141004, Ludhiana, Punjab, 2016.

[33] V. Kumar and Y. S. Shivay, "Integrated nutrient management: an ideal approach for enhancing agricultural production and productivity," Indian Journal of Fertilisers, vol. 6, pp. 41-57, 2010.

[34] M. Kassa, B. Yebo, and A. Habte, “The response of Haricot bean (Phaseolus vulgaris L.) varieties to phosphorus levels on Nitosols at Wolayita Zone, Ethiopia," American Journal of Plant Nutrition and Fertilization Technology, vol. 4, pp. 27-32, 2014.

[35] R. Li, R. Tao, N. Ling, and G. Chu, "Chemical, organic and bio-fertilizer management practices effect on soil physicochemical property and antagonistic bacteria abundance of a cotton field: implications for soil biological quality," Soil and Tillage Research, vol. 167, pp. 30-38, 2017. 